\title{
Islamism: What is New, What is Not? Lessons from West Africa
}

Ousmane Kane*

\begin{abstract}
In the aftermath of the Islamic Revolution in Iran of 1979, a marked scholarly interest in Islam driven by policy concerns developed in Western countries. Hitherto the monopoly of a few Orientalists, Islamic studies soon became a multidisciplinary field, attracting experts across the spectrum of the social sciences and the humanities, and indeed beyond academia, and many studies were carried out on Islamism. This article, which focuses on West Africa, questions some of the widely held assumptions on Islamism. The author's main argument is that Islamism is not a new phenomenon. A second point made here is that 'Islamist' movements are not primarily Salafi. A third point is that 'Islamists' are not inherently violent. What is new, according to the author, is the perception of Islamism as a threat in the West.
\end{abstract}

\section{Résumé}

Au lendemain de la révolution islamique iranienne de 1979, une abondante litérature a été produite en Occident sur l'islamisme en réponse à la demande des décideurs politiques. Jusque là l'apanage de quelques orientalistes, l'étude de l'islam est devenue un champ de recherches multidisciplinaire impliquant des chercheurs dans toutes les branches des sciences humaines et sociales. Cet article, qui est axé sur l'Afrique de Ouest, questionne de nombreuses idées recues concernant l'islamisme. L'idée maîtresse de l'article est que l'islamisme n'est pas un nouveau phénomène. L'auteur fait également valoir

* School of International and Public Affairs, Columbia University, New York, N.Y 10027. Email:ok2009@columbia.edu. 
que les islamistes ne sont pas majoritairement salafi. Enfin, il défend l'idée que les islamistes ne sont pas violent par essence. Ce qui est nouveau, d'après l'auteur, c'est la perception que l'Occident a de l'islam comme danger en Occident.

\section{Introduction}

As a graduate student in Islamic Studies in Europe, I learnt from the works of the European experts on modern Islam that 'Islamism' is a twentieth-century phenomenon starting with the rise of Egyptian society of the Muslim Brothers of Egypt and reaching its peak in the 1970s after the decline of Arab nationalism in the aftermath of the defeat of Arab armies in their war with Israel. This grand narrative has contributed largely to setting the terms of the debate on 'Islamism' in France in particular. Olivier Roy, for instance, argues that: 'Beginning in the 1930s, Hasan al-Banna, the founder in Egypt of the Muslim Brotherhood, and Abul-Ala Mawdudi the creator of the Indo-Pakistani Jamaat-i-Islami party, introduced a new movement of thought ${ }^{1}$ that endeavored to define Islam primarily as a political system, in keeping with the major ideologies of the twentieth century' (Roy 1994:viii). In the same vein, Gilles Kepel argues that 'In the Muslim countries of the Mediterranean Basin and its environs, re-Islamization movements ${ }^{2}$ took over from groups inspired by Marxism in challenging the foundational values of the social order. This was during the 1990s' (Kepel 1994:13) Another French Islamicist, François Burgat ${ }^{3}$ wrote that: 'The Muslim Brothers organized as a party stating explicitly this-worldly ambition are the first to want to capture political power and to provide to the projects of the reformist trend the logistics of a state apparatus. In this sense, they may appear as the first Islamists' ${ }^{4}$ (Burgat 1988:46 my translation). This narrative is not limited to French Islamic studies. In his Good Muslim, Bad Muslim, which among other things, analyzes different historical Islamic militant movements qualified as 'jihad movements', Columbia University's Mahmood Mamdani states that 'political Islam was born during the colonial period' (Mamdani 2004:14).

While my own earlier work has been informed by this grand narrative (Kane 1998, 2003), the more I compare so-called Islamist movements of the twentieth century to the eighteenth- and nineteenth-century 'movements of revival and reform' (Rahman 1977) the more common denominators I find. In this article, I will first show the similarities between the rhetoric and strategies of twentieth-century Islamist movements and that of earlier ones. A second goal of this article is to ques- 
tion the widely held assumption that Islamism is primarily a Salafi phenomenon driven by Wahhabi ideology and Saudi oil wealth. The third and final goal of this article is to challenge the portrayal of Islamist movements by the Western media in particular as inherently violent and non-pragmatic. In conclusion, I will argue that what is really new is not so much the goals and strategies of Islamic militant movements, as much the Western perception of Islam as a threat.

\section{'Islamist' Movements are Not New}

In the last few decades, a multitude of terms have been used to describe the phenomenon of political Islam, by which I mean: the ideology of religio-political movements striving to establish an Islamic political order either by capturing political power or by initiating a societal transformation, which would ultimately lead to the rise of an Islamic socio-political order. These terms include 'Islamic fundamentalism', 'Islamic activism', 'Islamic integrism', 'Islamic radicalism', 'Islamic renewal', 'Islamic resurgence', 'Islamic revivalism', and 'new Islamic radicalism'. To avoid terms with a Christian connotation, some authors have reinvented the term 'Islamism'. In fact, the term is not new, at least in the French language. In writings of the nineteenth and early twentieth century, the French word 'islamisme' was used as a synonym of Islam (Houdas 1908; Bonet-Maury 1906). 'Islamism' gained wide currency not only in Western languages, but also ironically in Arabic, where the term has been translated as 'Islamiyya' for Islamism and 'Islamiyyun' or 'Islamawiyyun' for 'Islamists'. In the twentieth century, 'Islamists' are identified in the literature as Muslim militant groups that challenged the secularization of Muslim societies and polities and advocated Islamization of the law, the economy and the state as the solution.

It has been suggested that Islamist groups could be divided into two categories. First, there are groups with a stated political agenda aimed at capturing political power, labeled 'state-centered Islamists' (Mamdani 2004) or 'movements of re-Islamization from above' (Kepel 1991). Second, there are militants who emphasized the necessity to correct religious and social practices, known as 'society-centered Islamists' (Mamdani 2004) or 'movements of re-Islamization from below' (Kepel 1991). As we will discuss below, some movements blur this distinction. In what follows, we will consider the rise to prominence of militant Muslim movements in the postcolonial Muslim world and then compare them with earlier militant Islamic movements in Africa in particular to show the similarities. 
After the consolidation of their rule, European colonial masters forbade the implementation of what some deemed inhumane bodily punishments contained in Islamic criminal law, such as the amputation of hands as punishment reserved for thieves and death by stoning for adulterers. But legal reform did not extend to all spheres of social life. Regardless of the colonial power and its preferred type of rule (indirect or direct), the colonial state in Africa and Asia allowed Muslims to settle matters relating to marriage, divorce, inheritance, custody, as well as some commercial transactions, according to the dispositions of Islamic law, as codified by one of the main so-called Islamic schools of law.

After independence, the modernizing elites of virtually all predominantly Muslim countries undertook radical reform of family law, notably to empower women. They targeted inter alia the aspects of Islamic family law relating to polygamy, unilateral repudiation and unequal gender distribution of inheritance. Tunisia went further than other countries in its efforts at legal reform. A host of new laws were adopted to promote women's rights, including the criminalization of polygamy and unilateral repudiation. Senegal restricted polygamy and imposed the first wife's acceptance as a precondition to polygamy. However, the scope of implementation of the new family laws was limited. In Senegal, according to a survey conducted by Amsatou Sow Sidibe, more than 90 per cent of Muslims have ignored the new codes and continue to settle family law matters according to Islamic laws (Sidibe, cited in Villalon 1995:229). However, in many spheres, postcolonial state-building required the adoption of Western civil and commercial codes, which did not face serious challenges in the early postcolonial period, as they were central to the project of modernization and development. This is particularly true for the realm of commercial transactions, largely inspired by Western practices.

To achieve the goal of 're-Islamizing' postcolonial Muslim societies, militant Muslims have adopted diverse strategies from peaceful proselytization to armed opposition. Some groups focused on reIslamizing society, on the assumption that the Islamization of the state would follow after the society became 'Islamic'. This has been the case for most militant Islamic groups in Morocco, for example. Other groups, such as the Muslim Brothers in Egypt, combined charity work to gain and retain members with military operations in the 1960s (Mitchell 1969). As their spectacular and unexpected success in the Egyptian parliamentary elections of December 2005 has shown, they seem to be willing to play the democratic rules of the game. The result is that they are emerg- 
ing as the strongest opposition group in the Egyptian parliament. Other groups, such as the Islamic Salvation Front in Algeria in the 1990s, started peacefully and then resorted to violence when they faced repression (Martinez 2000). Among the most successful groups in capturing supreme political power or exercising great influence in government, one can cite the Ayatollahs under the leadership of Khomeini in Iran, the Jammat Islami in Pakistan, the Muslim Brothers in the Sudan under the leadership of Hasan Al-Turabi before he fell into disgrace, the Taliban in Afghanistan until they were for a period driven underground by the US invasion following the September 11 attacks in the US, Hizbullah in Lebanon, and finally Hamas in Palestine, the first Muslim political movement to be elected democratically in the Arab world.

Before the 1960s, with a few exceptions, the potential constituencies of militant 'Islamist' movements were quite limited. Since the mid-1960s, many Muslim nations have experienced both a series of setbacks in the development process and successive military defeats in the war of Arab countries against Israel, prompting some to engage in a kind of soulsearching, leading them to identify the causes of these failures in the internal weaknesses of Muslim societies. Leftists who still had faith in Marxism attributed the failures to conservative forces that delayed the formation of a militant working class that would have promoted revolution. Liberals attributed the failure to the absence of the rule of law and a weak civil society that could not hold the state in check. Although the end of the Cold War and the triumph of neo-liberalism created hope in the 1990s that most nations were in transition to democracy, a growing consensus has emerged in the last few years that the consolidation of democracy is far from granted and that most so-called regimes in transition still maintain many attributes of authoritarianism (Carothers 2002; Levitsky and Way 2002). A third group, which had a strong appeal to sections of the Muslim youth and the middle class, came to diagnose the developmental failure and 'decline' of Muslim societies in their adoption of Western civil and commercial codes and institutions and suggested that the dismantling of such codes and their replacement by Islamic ones would be the panacea. For most of them, the Islamic Revolution of Iran became the tangible corroboration that greater self-reliance and Islam could indeed provide an alternative (Esposito 1984:169; Esposito and Piscatori 1990:319).

When a new vocabulary gains currency, the question that requires an answer is whether it successfully captures a new class of people or activi- 
ties. If not, there is a compelling case for a new term. In the case of Islamism, I doubt that this is the case. The twentieth century has witnessed the most dramatic changes in all aspects of human life, including European colonization of much of the developing world, two world wars and several other wars of decolonization, tremendous technological progress, the rise and decline of authoritarian regimes, and the spread of new forms of social organizations and technologies of rule. All this had had a tremendous impact in the world in general, and in Muslim societies in particular. Alongside change, however, there have also been remarkable continuities, including in the rhetoric and strategies of Islamic social movements. To highlight such continuities, I will turn to the discussion of Islamic revival in eighteenth- and nineteenth-century West Africa, a region relatively neglected in the debate about 'Islamism', which has largely focused on the so-called Central Muslim lands to the detriment of the periphery.

\section{Revival and Reiorm in West Airica}

From North Africa across the Sahara, Islam made inroads into the Western Bilad al-Sudan from the ninth century. ${ }^{5}$ From the ninth to the sixteenth centuries, the spread of Islam was very slow and much of the conversion was limited to the royal courts and circles of merchants involved in the trans-Saharan trade (Hiskett 1984:19; Triaud and Robinson 1997: 10; Levtzion and Pouwels 2000:2). Rulers who converted to Islam did not attempt to Islamize their subjects, not least because their legitimacy rested largely on local values and beliefs. Muslim clerics who staffed the administration of many of these African precolonial kingdoms did little to challenge non-Islamic practices of nominally Muslim rulers whom they served. The attitude of learned Muslims towards their non-Muslim neighbors was that of peaceful coexistence. This was partially explained by the fact that Muslims were a minority and therefore could hardly impose their religion (Triaud and Robinson 1997:10). However, it also rested on an ideological justification elaborated by al-Hajj Salim Suwari, who lived in the late fifteenth century and originated from Masina (in present-day Mali). Many hagiographies on Suwari circulated widely in Senegambia, and in particular among the clerical group known as the Jakhanke. Suwari's teachings were based on the principles that unbelief was the consequence of ignorance and that God's grand design for the world is such that some people would remain longer in the 'state of ignorance' than others. Conversion would occur in due course, accord- 
ing to God's plans (Wilks 2000:98). Consequently, both proselytizing and military jihads were unacceptable interference with God's will. Suwari also taught that non-Muslim rule was not only acceptable to Muslims, but should be supported by the latter insofar as it enabled them to follow the Sunna of the Prophet (Wilks 2000:98). Above all, Suwari believed that Muslims should pursue the search for education and provide 'unbelievers' with a model that they could emulate in due course when the time of conversion came, according to God's plans (Wilks 2000:98). Such a worldview enabled the Juula to engage in peaceful trade with the Gentiles for several generations (Hiskett 1984:170).

The seventeenth century witnessed a pattern of change as some Muslim clerics began to challenge 'non-Islamic rule'. Coming from the southwest of present-day Mauritania, the first cleric to advocate and fight for reform was the Berber scholar Awbek b. Aschfaghu, known as Imam Nasir al-Din (Robinson 2000:133), who belonged to the maraboutic tribe of Banu Dayman. He rebelled against the domination of the Bani Hassan, Arab-speaking warrior peoples, whom he portrayed as bad Muslims. The key ideas that influenced Nasir al-Din were the anticipation of the end of time and the arrival of a Muslim eschatological figure known as the awaited Mahdi and the notion of the Prophet Muhammad as a perfect man, which provided ideological justification for perfection to be realized through Islamic reform (Hiskett 1984:140).

Nasir al-Din's goal was to set up a unified community living according to Islamic sharia under the leadership of an imam, namely Nasir alDin himself. He recruited Wolof and Fulbe followers in the Senegambian region, who in 1670 succeeded in overthrowing the ruling dynasties in the neighboring Senegambian states of Cajoor, Jolof, Walo, and Fuuta Toro. The reform movement led by Nasir al-Din is known as the Shurbubba war, a term that refers to the war of clerics to establish a state governed by Islam.

Early efforts for reform were not successful in establishing lasting Islamic entities in the Western Sudan as Nasir al-Din was ultimately killed in a battle and the Bani Hassan reasserted their domination in southwestern Mauritania. Likewise, his followers' domination over Senegambian kingdoms lasted barely ten years as former rulers of these kingdoms garnered support from the French to reconquer their lands. However, the jihadist impulse in the spirit of 'Shurbubba' remained alive among some disciples of Nasir al-Din who strove to communicate their vision of an ideal Islamic society to future generations. 
Unlike Juula Muslims whose main mode of subsistence was commerce and who stayed away from subversive movements that would upset these profitable business arrangements (Hiskett 1984:170), the revolutionary movements of reform and state-building in eighteenth- and nineteenth-century West Africa were largely led and backed by the agriculturalist/pastoralist Fulbe (Triaud and Robinson 1997:11; Robinson 2000:131; Last:1987 passim). That they longed for the Islamic ideal described in the books of the classical period they had read is obvious. However, their movements did not emerge in a social or economic vacuum. The increasing levels of violence, taxation, and enslavement of Muslims were key factors that shaped the emerging jihadist attitude among Muslim clerics (Robinson 2000). Unlike court ulama, jihadist-minded clerics operated far from state courts. They were able to organize themselves and to train enough disciples to pursue jihad. From the beginning of the eighteenth century until the 'scramble for Africa' in the late nineteenth century, these militant Muslims waged a number of successful movements of reform, captured supreme political power, and created Islamic states in West Africa. The Fulbe revealed themselves to be much more aggressive and less tolerant than Mandinka-speaking clerics in the Suwarian tradition of peaceful coexistence with the Gentiles. Five of the Fulbe movements deserve particular mention: the jihads of Karamokho Alpha in Fuuta Jallon, the Torodbe Revolution in Fuuta Toro and Fuuta Jallon, the Jihad of Al-Hajj Umar and that of Usuman dan Fodio in present-day Northern Nigeria. ${ }^{6}$

The leaders and contexts of these West African revolutions of the eighteenth and nineteenth centuries share many commonalities with each other and with those of so-called Islamist movements of more recent times, including the sense of alienation vis-à-vis their environment, their attribution of economic and social problems to the failure to establish God's rule, and their critical attitude towards the court ulama.

Regarding their sense of alienation vis-à-vis their environment, Nasir al-Din, Sulayman Bal, Karamokho Alpha, Usman DanFodio, and Ahmadu Lobbo charged respectively the rulers of the Fuuta Toro, Fuuta Jallon, Masina, and Gobir with failing to govern according to the methods that Allah had revealed. This argument is identical to more contemporary thinkers of political Islam. One such thinker is Sayyid Qutb (190666), one of the most famous 'Islamist' theorists and activists of the twentieth century. Unlike previous Muslim reformers who had attempted to build a bridge between Islam and the West, such as Al-Afghani, 
Muhammad 'Abduh, or Rashid Rida, Sayyid Qutb saw nothing good in the West whose influence he thought Muslims should avoid. In his book Signposts on the Road, Ma'alim fi al-tariq (1964), Qutb, who had studied at Stanford University and the University of Colorado, submitted that sovereignty belongs only to God and based his claim among other arguments, on the reinterpretation of three verses of the Koran:5.44, 5.45, and 5.47. These verses respectively read as follows: 'he/she who does not judge by which Allah has revealed, such are the unjust; he/she who does not judge by which Allah had revealed such are the evil-doers; he/ she who does not judge by which Allah has revealed, such are the unbelievers'.

To the Arabic word ' $\mathrm{hkm}$ ', which occurs in all three verses, earlier interpretations attributed the meaning of 'to judge'. In contrast, Qutb interpreted ' $\mathrm{hkm}$ ' as 'to rule' and concluded that only those who rule as Allah has revealed are legitimate and must be obeyed. Conversely, he argued, societies not governed by Islamic constitutional, civil, commercial, and penal laws fall in the realm of what he qualified as 'Jahiliyya', ignorance. True Muslims must withdraw from such a society in the same way as the Prophet Muhammad, who left Mecca in the 622, to seek refuge in Medina. Furthermore, true Muslims should make it a priority to bring down those illegitimate rulers and have them replaced by real Muslims who would establish the rule of God.

The authoritarian socialist/nationalist regime of President Gamal Abdul Nasser of Egypt under which Qutb lived was the primary target of this criticism, but Qutb also included all other regimes not governed by Islamic law. Sayyid Qutb was ultimately hanged by Nasser's regime, but his writings were translated into several languages and exercised a profound influence on late twentieth-century militant Islam, not only in the Arab world, but also in Asia, Sub-Saharan Africa, and among Muslim communities in the West. In Egypt, the Society of Muslims, known also as Takfir wal hijra, led by Shukri Mustafa is one such group, which withdrew from Egyptian society to live in autarky. Qutb was also a source of influence on the Brothers in Nigeria led by Ibrahim al-Zakzaky, whose members abstain from working in any government on the grounds that the secular government is a system based on unbelief (i.e. a kufr-oriented system).

Another common denominator is that West African Muslim reformers of the eighteenth and nineteenth centuries and so-called Islamists of the twentieth century both operated in the context of social and eco- 
nomic deprivation, which, they held, was the responsibility of their rulers. Their perspective was religious in the sense that they worshipped God to gain salvation in the Hereafter. But it was also political as it served the purpose of capturing political power. Modern 'Islamists' spoke vehemently against elite corruption and the failure of rulers to cater for the need of populations. They criticized the failure of the postcolonial development project, the aggravation of poverty and unemployment and the enrichment of political elites. They also organized networks of selfhelp to relieve impoverished populations. Likewise, West African Muslim reformers of the eighteenth and nineteenth centuries spoke against the many taxes levied by rulers on populations and attempted to mobilize marginalized groups against rulers in a project of social and political transformation that would transfer power from oppressive rulers to reformers and their followers.

A third common denominator is their critical attitude towards court ulama for the latter's compromising attitudes towards a non-Islamic order. As highlighted in the earlier discussion of the Suwarian tradition, for centuries many learned Muslims worked in the courts of kings. They provided the latter with protective talismans, helped them chronicle history, and so forth. But most of them did not preach a 'strict religion' to the many nominally Muslim kings whom they served. Yet the latter, alongside Islam, continued to practice pagan cults, drink alcohol, which is forbidden in Islam, and entertained a harem, which exceeded the allocation of four wives. Unlike urban-based court ulama or merchant ulama, who had a vested interest in preserving the status quo, most West African leaders and rank and file members of revival and reform movements were based in rural and self-sufficient agricultural communities. They emphasized the acquisition of knowledge and the strict observance of faith according to the Maliki school of law. They harshly criticized court ulama for failing to fulfill the duty of commanding right and forbidding wrong (amr bi-il ma'ruf wa al-nahy an al-munkar in Arabic). Likewise some contemporary 'Islamists' have also criticized establishment ulama for implicitly endorsing the perpetuation of a non-Islamic status quo by not preaching against it. A case in point is the Egyptian 'Islamist' ideologue Abdusalam Faraj, who in the tradition of Sayyid Qutb, published in 1981 a pamphlet entitled Al-farida al-gha'iba (the hidden imperative). The core of Faraj's argument was that Islam not only rests on five fundamental pillars (faith, prayer, tithe, fasting, and pilgrimage), but there is a sixth obligation that 'status quo' ulama failed to emphasize: to dismiss a 
ruler who does not rule as Allah has revealed. Khalid Islambuli, who assassinated the former Egyptian President Anwar al-Sadat in 1981, claimed to have killed Pharoah, thereby fulfilling the sixth imperative of the faith.

As argued by Mervyn Hiskett, the common denominator of Islamic precolonial jihads in West Africa is that they had a vision of a single worldwide Islam, in which the way of life, the way of government, the morality and social behavior of all individuals were regulated strictly according to the Shari'a and the Sunna, the Law and the Tradition of the Prophet' (Hiskett 1984:170). This vision is a major common denominator between Muslim militant movements of the precolonial period who rose against unjust and impious rulers, Muslim militants who resisted against European colonial domination, as well as postcolonial Muslim militant movements that challenged secular governments in predominantly Muslim countries. This leads to the discussion of the claim that political Islam is predominantly Salafi.

\section{'Islamist' Movements Are Not Primarily Salaii}

Derived from the Arabic root salaf, which means to precede, the term Salafiyya designates 'the pious forefathers', al-salaf al-salih. Salafiyya is based on the belief that earlier generations closely followed the teachings of the Prophet in the Koran and the Sunna (Tradition of the Prophet Muhammad). Central to the Salafi creed is the notion that many Muslim problems arise from the fact that Muslims have gone astray by committing innovation (bid'a), by which is meant beliefs and practices that could neither be traced to the Prophet Muhammad nor to the salaf or pious forefathers. Such innovations resulted either from foreign influences introduced by converts to Islam or popular beliefs, superstitions and practices that were remnants of the pre-Islamic era. ${ }^{71}$ The solution to the predicament of Muslim societies was to get rid of all these blameworthy innovations.

Two leading types of Salafiyya can be distinguished. First was a moderate Salafiyya, an intellectual and political trend represented by the teachings of Jamaladdin al-Afghani (1838-97), Muhammad Abduh (1848-1905), and Rashid Rida (1865-1935), which attempted to build a bridge between Islam and the West. Second, a more radical Salafiyya can be traced to the teachings of thinkers such as Ibn Hanbal (780855), Ibn Taymiyya (1263-1328), and Muhamamad Ibn Abd al-Wahhab (1703-92). This branch of Salafiyya, which influences the thinking of 
such modern groups as the Wahhabi or the Taliban, tends to have a very rigid and literal interpretation of the Koran. Although there is some overlap between these radical Salafists and political Islam, by no means are all 'Islamists' Salafi. I contend that what has made the argument equating Salafism and 'Islamism' gain so much currency is the perception of Wahhabi-minded groups as a threat.

The increasing wealth of the conservative Persian Gulf nations and the commitment to supporting the spread of Wahhabism motivated many Saudi charities and NGOs, with the blessing of the Saudi state, to fund groups committed to proselytizing. During the Cold War, the US Central Intelligence Agency and the Pakistani secret services infiltrated these Islamic organizations to recruit jihadists to fight against the Soviet Union in Afghanistan. Although most of these jihadists were devout Muslims and anti-imperialists, who were convinced they were fighting for a just cause, they were nevertheless on the side of the US and its allies during the Cold War. Subsequently, some fought in Chechnya and Algeria. After the end of the Cold War, jihadists targeted Western interests as well as their own government. Their activities attracted the attention of the Western media, the general public and numerous scholars.

Gilles Kepel (2000), for instance, painstakingly analyzes the context of the rise of political Islam in the Muslim world in the 1970s. Drawing evidence from North Africa to Egypt, Turkey, South and South-East Asia, Kepel situates the rise of Islamism within the context of the decline of Arab nationalism and the rise of Saudi Arabia to prominence. To make sense of Islamism, he surveys the role of immigration, pilgrimage from different parts of the Muslim world to the Gulf, the rise of the Islamic banking system and the proliferation of Saudi charities. In the final analysis, however, Kepel lays considerable emphasis on the role of Saudi Arabia in the rise of the new Islamic radicalism. After the oil boom, argues Kepel, inexhaustible funds were now available to promote the $d a$ 'wa or call to Islam, through Wahhabite preaching' (Kepel 2000:72).

While the diffusion of Saudi oil wealth has no doubt played a role in the expansion of political Islam, its importance has been largely exaggerated. The argument equating 'Islamism' to Salafism and tracing it to the diffusion of Saudi generosity is flawed for at least three reasons.

First, it assumes that Saudi funding went primarily to Wahhabi-oriented groups. Some pro-Wahhabi groups did get financial support from Saudi religious authorities, but they did not enjoy a monopoly of Saudi funding. Prominent Muslim leaders throughout the Muslim world ben- 
efited from Saudi largesse. Saudi Pan-Islamist policy can be traced to the 1960s during King Faysal's rule. Although committed to a certain extent to spread Wahhabism globally, Pan-Islamism also aimed to curtail the influence of Nasser's nationalist Pan-Arabism, which conservative monarchies perceived as a threat. Within that framework, Saudi Pan-Islamism searched for a broader legitimacy than Wahhabi-minded groups could provide. It targeted prominent Muslim groups throughout the Muslim world, and not only Wahhabi-minded groups. Some of the founding members of the Muslim World League, which is the instrument par excellence of Saudi Pan-Islamism, were not Wahhabi at all. For example, take the Sufi Shaykh Ibrahim Niasse from Senegal (190075), a towering figure in the history of West African Islam in the twentieth century (Seeseman 2004:v) and who in the early 1960s was a founding member and Vice-President of the MWL (Schultze 1990:192).

Second, no matter how generous, Saudi Arabian NGOs have not been able to fund all Wahhabi-minded groups in the Muslim world. Most of them, I would argue, did not receive significant funds from Saudi Arabia for proselytization purposes. Rather, they raised their funds locally. This was certainly true of the Society for the Removal of Heresy and Reinstatement of Tradition, which is the largest single Muslim reform organization in Sub-Saharan Africa (Kane 2003; Loimeir 1997).

Third, many Wahhabi groups in Nigeria, Mali, Senegal and elsewhere emphasized the reform of religious practices but abstained from challenging ruling elites in their countries and did not seek to capture political power.

The literature arguing that Salafism is a fundamental feature of political Islam tends to distinguish Sufi orders from 'Islamists' for at least four reasons:

- the orders are viewed as syncretic whereas so-called 'Islamist' movements emphasize the return to the fundamental sources of Islam, namely the Koran and Sunna;

- the orders are construed as conservative and pro-status quo whereas so-called Islamist movements are construed as subversive (Kepel 2000:48-50);

- the orders are said to appeal primarily to illiterate people whereas 'Islamists' are said to be the product of modern or Westernized education (Kepel 2000); 
- the orders are believed to recruit largely among so-called traditional peoples (in rural or 'tribal' areas) whereas so-called Islamist constituencies are urban and modern (Kepel 2000).

This dichotomous construction has gained wide currency thanks to the writings of influential anthropologists of Muslim societies, notably Clifford Geertz and Ernest Gellner (see Geertz 1968; Gellner 1969, 1981). Both scholars tend to present these two forms of Islam as polar opposites. In reality, there is a great deal of diversity among the Sufi orders. The popular Sufism presented as an archetype by Geertz and Gellner is only one variant of Sufism. In eighteenth- and nineteenthcentury Africa, at least three expressions of Sufi Islam could be found (Brenner 1987:81).

The highly individualized variant is the first and oldest expression of Sufism. Its adepts focused on devotional and spiritual practices and did not employ the orders as a basis for social or political action (Brenner 1987:82). Pre-nineteenth century Mauritanian and other West African orders are cases in point (Brenner 1987:82; Salih 1992:103-24). The second type of Sufi orders conceived of themselves as a corporate group, but were loosely structured and above all subsumed within other communal structures such as the family, tribe, ethnic group, etc. (Brenner 1987). A third category comprises highly structured and politically active Sufi groups (Brenner 1987). These new orders developed during the eighteenth and nineteenth centuries and provided the inspiration for reform and state-building movements that swept across 'Sudanic' Africa. They were centralized; their leaders as well as many rank and file members were highly educated; they also recruited massively and operated autonomous agricultural organizations independent of royal courts; Finally, they were active in protest movements. Therefore, they blurred the boundaries between mystical, legal and political Islam. Their emergence was part of an effort of revival and reform that reached its climax during the second half of the eighteenth and the beginning of the nineteenth century (Rahman:2000; Esposito 1984:30-57; Voll:1994:24-83). As Bradford Martin rightly argues:

... dedication to mysticism in no way hindered many of them from being practical leaders of causes quite as much as being mystics or intellectuals, and that most of them had expressed ideas in writing. Also, most of them were very much in the contemporary intellectual mainstream, they rejected blind imitation of what earlier thinkers had done. They very often showed their great intellectual 
independence over such matters as hijra ('removal', 'withdrawal'), particularly in the face of a colonial takeover by some alien power, and expressly opted for a form of juridical freedom (ijtihad) when it was appropriate (Martin 2003:ix).

The eighteenth- and nineteenth-century movements of revival and reform in Islam took place as the dying Ottoman Empire, last rampart of past Muslim glory, was undertaking radical reforms to halt its own decline, including the adoption of three constitutions known as Tanzimat. These measures fell short of curing the Sick Man of Europe, as Turkey was named by Western chancelleries engrossed in debate about the fate of the empire. The preoccupation with reform was certainly not limited to official circles of the Ottoman Empire as many Muslim intellectuals and activists believed that something ought to be done. As Albert Hourani has documented so well in his seminal work on Arabic thought (Hourani 1983), some Muslims strove to bridge the growing divide between Islam and the West (the moderate Salafis), while others submitted that the return to the model of the Prophet was the only solution (the radical Salafis).

Sufi orders were also part of this general effort of revival and reform. They envisioned reform as the combination of devotional Sufi spiritual exercises based on individual and collective recitation of litanies aimed at purifying their soul; the study of the Sunna (tradition of the Prophet Muhammad), which should serve as a model for all believers; and the waging of the jihad of the mouth (jihad al-qawl) to spread the right faith, and when it fails, the resort to the jihad of the sword to topple 'unjust' rulers and establish the rule of God.

The organizational structures of these centralized orders differed. The Tijaniyya, a widespread Sufi order in contemporary Africa, was organized as follows: at the summit of the hierarchy, was the supreme shaykh. This position was occupied by Ahmad al-Tijani of North Africa during his lifetime, and his heir after his death. Before his death, the supreme shaykh usually appoints a successor, often his oldest son, but sometime a trusted lieutenant. He also appoints first-class deputies known as khalifa (pl. khulafa) to represent the order in other regions or countries. Khulafa are awarded the itlaq (authorization to initiate disciples, transmit esoteric knowledge and even to deliver supreme ijaza). The appointed representative of the Tijaniyya in Black Africa, Al-Hajj Umar Tall (17971864) of West Africa, is a case in point. A rank lower is that of secondclass deputies (muqaddam), who are only allowed to initiate a limited 
number of aspirants to the order. Finally, aspirants receive initiation and are allowed to recite basic rituals but do not enjoy the privilege to initiate or transmit knowledge. Deserving aspirants could, of course, rise in this ladder to the rank of muqaddam of khalifa.

This hierarchical structure of the orders allowed for geographical decentralization of authority. Deputies would pay allegiance to the supreme shaykh, but enjoy considerable autonomy in dealing with their own constituencies. Most of these orders emphasized the study of the Hadith (sayings of the Prophet Muhammad) and the necessity to transcend the narrow jurisprudence of the four legal Sunni schools of law through a resort to ijitihad or attempt to find a solution to the social and political problems of the day (Brenner 1987:82).

Usman Dan Fodio wrote on Islamic mysticism (tasawwuf), political activism (issues related to the jihad), theology and jurisprudence (Martin 2003:23-4). His writings were influenced by the teachings of his master, Jibril b. Umar, a radical Tuareg teacher from Agades (Martin 2003), but his indignation towards the exploitation of the masses by Habe rulers shaped the course of his life as reformer and state-builder. The spearheads of the jihad in early nineteenth-century Hausaland, although not Wahhabi, had an agenda of reform. They mastered the Islamic jurisprudence and preached its rigorous implementation. They also anathemized 'venal' scholars who manufactured talismans for, or worked in the court of kings (Bradford 2003:28). In general, these so-called venal scholars did not see as contradictory the combination of Islamic and local African thaumaturgy. As Africans of different faiths believed in the efficiency of local talismanic sciences that combined Islamic and African magical knowledge, both Muslim and non-Muslims cooperated (Brenner 2000), finding magical solutions to the hardships encountered in their daily lives, caused by disease, climatic phenomena such as drought, hunger and the general insecurity related to slave-raiding. Unlike the Wahhabi whose Salafism entailed the rejection of Sufism, West African Sufi reformers believed that Sufism was the highest expression of Islamic 'orthodoxy' and criticized syncretism.

The ideal types (rural/urban, literate/illiterate, conservative/subversive, syncretic/Salafi) that serve to contrast Sufi and 'Islamists' do not withstand careful historical scrutiny. The Sufi milieu is well known for its diversity and complexity. If Salafi movements are essentially urbanbased and appeal to literate strata, Sufi orders recruited across the geographical and social spectrum. If 'Islamists' tend to be subversive, they 
do not have the monopoly of this political orientation because some Sufi organizations have attempted to capture political power by force. Moreover, the propensity towards subversion or conservatism is inherent neither in Sufi orders nor among 'Islamists', but rather is contingent on the political circumstances in which they operate.

The point can be illustrated by the Tijaniyya Sufi order. In Algeria, the Tijaniyya allied with the French, not because of any inherent inclination towards collaboration but in order to counter two enemies. On one hand were the Ottoman Turks who defeated Tijani forces and publicly decapitated the leader of the Tijaniyya, Muhammad al-Kabir al-Tijani. The other enemy was Emir Abd al-Qadir al-Jaza'iri, a Qadiri who was supported by other rival Qadiri groups. The subsequent alliance of the Tijaniyya with the French during colonial rule served strategic purposes. The Algerian Salafi were very much part of the struggle for independence from colonial rule. It was no wonder that postcolonial official Algerian rhetoric demonized Tijaniyya shaykhs, labeling them colonial collaborators and accusing them of practicing a syncretic Islam.

In Sub-Saharan Africa, the spearhead of the same Tijaniyya, al-Hajj Umar, fought against French expansion in West Africa. So did his son and successor Ahmad al-Kabir. However, after the collapse of his empire, his grandson, Sa'id Nur Tall, became the closest ally to the French colonial rule of the entire Muslim establishment. Not only was he awarded the highest and most prestigious medals and distinctions of the French colonial state, but he was also appointed Khalif General for West Africa, in effect the highest Islamic authority in West Africa (Garcia 1997). In Mauritania, Sufi families were divided regarding the attitude to adopt towards the French colonizers. The Qadiriyya Fadiliyya is a case in point. Shaykh Saad Buh was an ardent supporter of French colonial rule whereas his brother Ma al-Aynayn vigorously opposed French expansion and fought with his troops against them (Ould Abdallah 1997). During colonial rule, some Sufi orders were part of the colonial establishment in West Africa while others maintained minimum contact with colonial rulers.

There is no doubt that Sufi groups appealed to the illiterate and those inclined to worship local saints, but they also provided networks of schools in which both esoteric and exoteric knowledge were offered. Most Sufi lodges (zawiyas) operated schools and provided Islamic knowledge to members in search of knowledge. They emphasized the study of Islamic law and like modern 'Islamists' they retain the right to ijtihad. The growth 
of literacy was largely due to the efforts deployed by Sufi orders, particularly in the aftermaths of the eighteenth- and nineteenth-century jihads. As revealed in the manuscript heritage of West Africa, Sufi shaykhs produced a literature in Arabic, Fulfulde, Hausa, Kanembu, Wolof and other African languages with the Arabic script. This literature includes devotional poems praising the Prophet in the tradition of Sufism, legal opinions (fatwa), and political writings (Bobboyi 2008). Usually in the form of poems condemning the arbitrary and exploitative rule of the precolonial Hausa kings of northern Nigeria, this literature served to mobilize a community of the Faithful longing for the overthrow of Hausa rulers and establishing a just society (Bobboyi 2008).

As rightly argued by Mervyn Hiskett (Hiskett 1984:242) the West African jihads of the eighteenth and nineteenth centuries were not only political, but also intellectual revolutions. The emergence of an Islamic clergy provided the sociological foundations for these revolutions. For the first time in West African history, Muslim clerics, hitherto a tolerated minority, overthrew many rulers, many of whom were illiterate, and replaced them. Therefore, some Sufi orders were undoubtedly politically active and stood against Western imperialism in the nineteenth and early twentieth centuries. But a question that requires an answer is whether Sufi groups have contributed to the recent Islamic revival. To answer this question, I will address the Islamic revival in Senegal and Nigeria.

The Senegalese Da'irat al-mustarshidin wa 'l-mustarshidat (Circle of men and women seeking guidance) is one of the largest 'Islamist' movements in West Africa (Samson 2005). It claims half a million members, based mostly in Senegal with branches in neighboring West African countries, Europe and the USA. Although this claim has not been independently confirmed, the Mustarshidin movement remains the largest neoSufi movement in Senegal. It was founded by Cheikh Tidiane Sy and his son Moustapha Sy, both members of a major Senegalese Tijani lineage. They have at times supported the former ruling party of Senegal (Parti socialiste sénégalais), and at other times led movements of protest against it. During the campaign for the Senegalese presidential elections of 1993, the Mustarshidin mobilized the youth to protest against the ruling party and constituted the most serious religious and political opposition to face the ruling party since Senegal became independent in 1960 (Kane and Villallon 1998). 
Northern Nigeria is another case where 'Islamism' is not predominantly Salafi. After Nigerian independence in 1960, Nigerian Muslims adopted a largely secular criminal code. They also accepted the idea of a federation in which no religion would be a state religion. Only a small minority of Muslim students spoke out against the secular state and advocated throughout the 1980s and much of the 1990s that Nigeria should become an Islamic state. In 1999, the governor of the tiny northern state of Zamfara re-enacted Islamic criminal law. Subsequently, Muslims of all persuasions, including members of Sufi orders, in all other predominantly Islamized states of northern Nigeria voiced demands for the reintroduction of Islamic criminal law. As a result of popular pressure, eleven of the northern states of the Nigerian federation introduced some form of Islamic law in their criminal legislation. Thus, no particular doctrinal persuasion has been more prone than others to political mobilization. Rather, it is the specific political contexts of struggle for influence and resources, which determine the political agenda of Muslim groups. This leads to the discussion of the perception of 'Islamism' as violent and irrational.

\section{'Islamist' Movements Are Not Inherently Violent}

From the late 1970s, a number of events in the Middle East contributed towards a growing fear about political Islam, and indeed about Islam in general in the West. Starting with the summary execution of members of the establishment of the former regime without due process of justice to the imposition of the veil on women, these excesses culminated with the storming on 4 October 1979 of the American embassy in Tehran by Iranian Muslim militants, who held 70 Americans captive for fifteen months. The kidnapping of Western hostages in Lebanon by the pro-Iranian Shiite group Hizbullah and the killing of almost a hundred Western tourists in Egypt between 1990 and 1995 did nothing to alleviate the fears inspired by some militant Muslim groups. In the 1990s, 'Islamists' became an even bigger threat. In 1993, a group of 'Islamists' attempted to bomb the World Trade Center in New York, causing minimum casualties as compared to what would happen on 11 September. In the interim, Usama Bin Laden, a former American ally in the war against the Soviets in Afghanistan, declared a war against America. His followers, known as operatives of al-Qa'ida, attacked the US embassies in Dar es Salaam and Nairobi in 1998, bombed the destroyer USS Cole in October 2000, and finally carried out the destruction of the World Trade 
Center on 9/11. These events were certainly the most audacious and devastating in the history of modern terrorism. To these developments, one must add the adoption of suicide-bombing tactics by Palestinians fighting against the Israeli occupation of Palestine. The media coverage of these events has provided many of the ingredients for equating 'Islamism' (and sometimes Islam in its entirety) with bigotry, violence and terrorism.

There are two main schools of thought that have attempted to make sense of the violence with which 'Islamist' movements are associated. For want of better terms I will call them respectively the culturalist and 'political talk' schools for lack of better terms. ${ }^{8}$

This classification is based on my personal interpretation and does not necessarily reflect the self-identification of the scholars whose views I discuss in this section.

Inspired by Weberian analysis along the lines of The Protestant Ethic and the Spirit of Capitalism, the culturalist school of thought is based on the assumption that culture shapes the behavior of individuals. It argues that socio-economic factors are not determinant in understanding the violent nature of al-Qa'ida and other jihadist organizations. It is rather the extremely intolerant Wahhabi doctrine that incites people to murder and violence (Gold 2003; Schwarz 2000). A more sophisticated variant of what I call the 'culturalist' school distinguishes between tangible and intangible incentives to join radical Islamist movements. Without dismissing the importance of tangible material benefits, this line of interpretation argues that: "movement ideologies offer strategies for fulfilling duties and maximizing the prospects of salvation on judgment day' (Wiktorowicz and Kaltenhalter 2006:295). And: 'Indoctrinated individuals viewed activism or even risk itself as a means to achieve salvation and entrance into Paradise. Guided by the movement ideology, participants viewed suffering and effort as a testament to the certitude of belief (assurance that they would achieve the spiritual payoffs). From this perspective, the strategy of high cost/risk is strategically rational' (Wiktorowicz and Kaltenhalter 2006:302).

The second school of thought, which emphasizes political talk, is informed by the assumption that what is at stake is not religion or culture, but grievances rooted in the deployment of imperial power (Mamdani 2004) and that the objective of terrorist groups is to force these powers to withdraw their military troops from a specific region (Pape 2005). According to Mamdani (2004:253-4), Bin Laden is not a 
theologian, but a politician, and nobody follows him for religious reasons (Mamdani 2004:253-4). The most important political motivation is their opposition to US imperialist policies in the Middle East, its unflinching support to the State of Israel and the violation of international law by both the US and Israel.

However, both lines of arguments tell only one part of the story. The Wahhabi doctrine has been elaborated over two centuries. During the 1950s, 1960s and 1970s, many people of Wahhabi inspiration spent their lives without ever being involved in acts of terror, either in Saudi Arabia or elsewhere. Until now, the majority of the people who claim to be Wahhabi have never resorted to violence. Therefore, the culturalist explanation is weak.

Typically inspired by secularization theory, the second explanation also poses a problem, as it overlooks the fact that religion and politics are not easy to separate if we want to understand Islamic politics. Religion, I argue, is an integral part of politics. Believers would typically pursue two goals in their lives: on the one hand, they participate in politics, defined as 'who gets 'what, when and how', and on the other hand, they strive to do what pleases God to gain salvation in the Hereafter. These two goals are inextricably interwoven.

Contemporary Saudi politics demonstrates that power needs religious legitimation as much as resistance does. Given that most al-Qa'ida operatives are Saudi, I will illustrate my points with the discussion of Saudi Islamic politics. The political and epistemological foundations of modern Saudi Arabia is based on an alliance between two individuals Ibn Sa'ud (d. 1765) and Muhammad b. Abd al-Wahhab (d. 1792), and subsequently between their descendants, al-Saud and al-Shaykh. The alliance between these two families not only entailed power-sharing agreements, but also intermarriages between these families. The class of Muslim clerics dominated by the al-Shaykh has been consulted in the most important decisions taken by the Saudi authorities (El-Tahri 2005). When, in the early 1930s, King Abd al-Aziz b. Sa'ud, the founder of the modern Saudi Kingdom, introduced technological innovations such as railways, cars and motorcycles in an effort to modernize the country, he faced strong opposition from the Ikhwan, the spiritual sons of the Wahhabiyya. The Ikhwan perceived new technology as an innovation contrary to the teachings of the Prophet Muhammad. King Abd al-Aziz turned to the ulama to seek legitimacy. The latter issued legal advice allowing the use of technology to serve the purpose of nation-building 
and to legitimize the crackdown on all those who opposed it, and hence the suppression of the Ikhwan (El-Tahri 2005). When Abd al-Aziz Ibn Saud needed resources to modernize his country and wanted to cut deals with Americans for oil exploration, he had to convince the ulama that there was nothing wrong in collaborating with non-Muslims as the Prophet Muhammad collaborated with Jews and Christians when he relocated to Medina (El-Tahri 2005). When King Saud, who succeeded King Abd al-Aziz, turned out to be incapable of governing, the ruling Saudi family concluded that deposing him was the only way out. They turned to the ulama, who issued a legal fatwa allowing them to depose King Saud. He was then exiled to Greece where he later died. In the late 1970s, when a group of extremists Saudis took over the Holy Mosque of Mecca and their leader claimed to be the awaited Mahdi, the Saudi regime had to seek legal advice again from the ulama before taking action. The latter declared that the insurgents were apostates. Only then did the Saudi troops with logistical help from the French attack the mosque and put down the revolt (El-Tahri 2005). When Saddam Hussein attacked Kuwait and upset the geopolitical balance of the Persian Gulf, the Saudi were not confident about the capacity of their troops to protect the kingdom. They turned once again to the ulama, who legitimized the coming of American troops to defend the country (El-Tahri 2005).

Similarly, opponents to power seek fatwa from some ulama to legitimize their opposition. Any attempt of analysis that separates political and religious factors would fail to accurately capture Muslim politics because the two are intimately interwoven. Suicide-bombers have received fatwas from ulama in support of the act of 'suicide'. When blowing themselves up, most of them (perhaps not all) are absolutely convinced that they are pleasing God. It is not suicide that they are committing (intihar in Arabic), but martyrdom that they are seeking (istishhad in Arabic).

However, to say that religion matters is neither a support for 'the clash of civilizations' argument, nor to argue that religious convictions can explain everything. As some of the preceding examples show, religious conservatism does not rule out collaborating with people from other religions or even with those without religion to promote strategic interests. The ideology of Wahhabi Islam did not prevent Saudi leaders from becoming the best collaborators of the US during the twentieth century since the strategic interests of the Saudi were at stake. Undoubtedly, religion is part of the political culture of 'Islamist' movements. Yet 
the ideology of religious radicalism does not necessarily lead to strong political opposition movements without grievances. In this respect, 'Islamist' politics is not any different from non-Islamic politics. It is also often largely based on rational calculation and pragmatism.

I argue that 'Islamist' movements are not more likely than secular political organizations to resort to violence. If the political terrain is democratic enough to allow fair political participation, 'Islamist' movements are likely to be driven to moderation (Kalyvas 2000). Lisa Anderson has rightly argued that 'the absence of a reliable, transparent institutional framework for political opposition to work within not only hampers the routinization of opposition of all kinds but magnifies the profile and broadens the constituency of "rejectionists" or "disloyal" parties' (Anderson 1997:19). She further argued that: 'as a general rule, the closer the [Muslim militant] movements were to the prospects of sharing power, the more pragmatic they are' (Anderson 1997:26). Conversely, under regimes of despotism, which have been the rule not the exception in the Arab/Muslim world, 'Islamists' are likely to go underground. For example, the Egyptian Muslim Brothers, who are one of the first mass militant Islamic movements in the twentieth century, started as a branch of a Sufi order committed to promoting the faith. They initially did not have a goal of bringing down the Egyptian monarchy, but sought to promote an Islamic ideal for society. After the coup d'état of the Free Officers in 1952, the Muslim Brothers sided with the military and emphasized social work to recruit membership. Their goal was to moralize public life and to preach for an Islamic purity. However, the autocratic rule of President Gamal Abdul Nasser of Egypt criminalized all forms of dissent and caused the political alienation of the Muslim Brothers, driving the latter towards a political radicalization.

In Morocco and Jordan, a large segment of Muslim militants participate in electoral politics and are not involved in organized violence. In Turkey, 'Islamists' won the elections in 2003 and formed a government, which does not differ in any way from the governments of other secular countries. Although its leaders are devout Muslims in their private life, they remain committed to secularism. The Turkish 'Islamist' government (a secular ruling party with 'Islamist' roots as it is called by some) is much more committed to joining the European Union than to promoting pan-Islamism. It is presiding over a fundamental reform of Turkish laws and mores in order to prepare the country for membership in the EU. In the field of family law, it has recently repealed a law 
criminalizing adultery, which is one aspect of the Islamic legacy. The current Turkish 'Islamist' government has taken more steps towards granting cultural and political rights to minorities than any preceding 'non-Islamist government'. For the first time since the creation of modern Turkey, Kurds are allowed to speak their language and operate radio and television programs in Kurdish. Hitherto, the mere mention of the name Kurd exposed people to repression. Indeed, the current Turkish government is likely to take other measures required to 'Europeanize' the country.

Hizbullah in Lebanon is another militant Muslim party, which tries to combine the use of military power to fight against the Israeli occupation of southern Lebanon, including the use of human bombs, with subtle political negotiation and alliances with Christians whenever this serves their strategic interests. Between 1982 and 1986, Hizbullah conducted 36 suicide terrorist attacks against French, American, and Israeli targets, killing 659 people (Alagha 2005:35; Pape 2005:129). In the parliamentary elections of June 2005, Shaykh Hassan Nasrallahn, the leader of Hizbullah, exhorted his followers to vote for candidates of the outlawed Christian militia, the Lebanese forces (Kifner 2005:16). I argue that 'Islamist' movements are neither irrational nor inherently violent. Where they can peacefully accede to power and influence society, they are as likely as any secular political groups to seek power through peaceful means. Most have resorted to violence when the terrain did not allow for peaceful political action. However, I must emphasize that I am not arguing that 'Islamist' movements are inherently democratic as there is no guarantee that once in control of government, they would not be tempted, like nationalist and socialist regimes, to monopolize power and criminalize political opposition.

\section{Conclusion}

In this essay, I have argued that there are many similarities between contemporary Muslim militant movements referred to as 'Islamist' and movements of revival and reform of the nineteenth century, and that there is no compelling case to use a new term to qualify the former. Had 'Islamism' been defined broadly to include earlier movements of preceding centuries, I would not have taken issue with the term. But defined as a twentieth-century ideology, the term 'Islamism' fails the test of providing new insights. I have also argued that Muslim militants striving 
to transform society or take power are not primarily Salafi, nor inherently violent. To refute the notion of the newness of 'Islamism', I have argued that the rhetoric of leaders of West African jihads in the eighteenth and nineteenth centuries shows a striking similarity to so-called Islamist movements of the twentieth century: a strong opposition to European hegemony, a denunciation of exploitation, and a commitment to fostering a political system governed by Islamic laws. With regard to anti-colonialism, the Sanusiyya in Libya, Niger and Chad opposed the British, the French, and the Italians. Similarly, the Tijaniyya of Umar Tall fought fiercely against French colonial domination in West Africa. The anti-colonial dimensions of their actions parallel very much the opposition to Westernization by many contemporary 'Islamists'. Nineteenth-century Islamic militants in West Africa aimed at replacing the dominant forms of mixed Islam in West Africa with a legal system based on the Shar'ia. Similarly, contemporary 'Islamists' have as their principal aim the dismantling of modern European-inspired legal codes and constitutions and replacing them with Shar'ia law.

Olivier Roy's point that Islamism was conceived to 'keeping with the major ideologies of the twentieth century' is an interesting one. It alerts to the influence that twentieth century ideologies may have had on 'Islamist ideologues'. Arguments along those lines have emphasized that contemporary political Islam is indebted to other ideologies such as socialism, constitutionalism and third-worldism for ideas of social justice, revolt against an unjust ruler or anti-imperialism. I concur that postcolonial Muslim militants were aware of competing ideologies, not least because they engaged in debates with communists, liberals and others on university campuses. It is also true that many contemporary ideologues of Islamism are quite at home with various ideologies born in the twentieth century. From Al-Afghani, Muhammad Abduh, and Rashid Rida in the late nineteenth and early twentieth centuries to Qutb, Mawdudi, Ghannouchi, Abbasi Madani and Hasan Al-Turabi, many Islamist ideologues have been steeped in Western liberal traditions. Hasan AlTurabi obtained his Ph.D. in Law at the Sorbonne, Abbasi Madani his Ph.D. in Education in Britain, Mawdudi was a journalist and Sayyid Qutb studied in the USA. Different ideologies may have had some influence on some contemporary Islamist ideologues. Such an influence, however, need not be exaggerated. As shown in the analysis of the worldview of eighteenth-and nineteenth-century militant 'movements of revival and reform', ideas of greater social justice, of the necessity to 
overthrow an unjust ruler, or to resist foreign occupation and exploitation are not foreign to the classical tradition of Islam and cannot be argued to date from the twentieth century. The fact that such ideas are articulated in contemporary 'Islamist' discourse does not result exclusively from the influence of various twentieth-century ideologies.

I have also argued that 'Islamist' movements are not primarily Salafi and that the opposition Sufi/Salafi is misleading since the whole purpose of the politically active and highly structured Sufi orders since the late eighteenth century has been to reconcile the divisions between a speculative and ecstatic Sufism and a more strict observance of the Shari'a. Here again, I have provided examples from West Africa to illustrate my point. I have also argued that Sufism does not only appeal to illiterate people looking for a personal incarnation of the sacred, as Gellner puts it, but also to the educated in society. In West Africa in particular, much of the growth of literacy is rooted in the educational efforts of the Sufi orders. Sufi Shaykhs wrote not only devotional literature: they also produced political writings criticizing the oppression and exploitation that many populations were suffering during the precolonial period. Indeed, they sometimes led wars of liberation in favor of those populations. I have also briefly documented the existence of this form of Sufi 'Islamism' in West Africa.

Finally, I have argued that 'Islamists' are not inherently violent and that 'Islamist' politics is no less pragmatic than secular politics. The resources and constraints of the milieu in which they operate determine to a great extent what strategy they adopt for their struggle, and whether the moderates or the hardliners within each 'Islamist' group would impose their agenda. If 'Islamists' can achieve their goals through peaceful means, they are not likely to rush underground.

The unanswered question remains: what is fundamentally new about Islamic militantism? No doubt that the context of their rise is new: the new Islamic movements born in the twentieth century appeared in the context of secularization of Muslim societies. While the project of secularization was introduced by European colonial rulers, it was pursued after independence by authoritarian and corrupt local rulers who not only failed to provide for their peoples, but also restricted their freedoms, and criminalized all forms of opposition. In voicing their opposition against secularized Muslim governments, new Muslim militants used a rhetoric that emphasized the return to pristine Islam and social justice rooted in a similar milieu to that of their predecessors. 
Another new development was the impact of the Islamic Revolution in Iran on international affairs. The successful 1979 Islamic Revolution led by Khomeini in what was previously considered as one of the most pro-Western countries in the Middle East was unquestionably a watershed in Western/Muslim relations. It came as a great shock to many Westerners because the revolution ousted a trusted ally of the Cold War. It also contributed to creating the image of Islam as a threat to the West.

A third new development is the new Islamic presence in the West. Increasing numbers of labor migrants, students and refugees from Muslim countries have settled in Western Europe and North America in the last three decades. The number of such Muslims in the early twenty-first century is estimated at some 30 million, an unparalleled presence in history. During the same period, proselytizing groups from Muslim countries such as the Tablighi Jama'at, the World Muslim League and many others have been committed to re-Islamizing Muslim communities in the West. They have made inroads in the suburbs of Paris, Berlin, Amsterdam, New York and London. With the help of devout students from Muslim countries, they strive to carve out a Muslim space in the West. Their efforts focus on establishing shops and restaurants providing Muslim halal food, mosques, on Islamic schools and cultural centers, research institutes, newspapers and charities. These Islamic institutions have proliferated in large European cities. In France alone, the number of mosques increased from 10 to almost 1,000 between 1960 and 1975 (Kepel 1991).

The efforts of recent immigrants are echoed in the public space by second-generation Muslims. Facing racism and exclusion in the West, some Arabs, Turks and African Muslims born in the West have started to assert their Islamic identity and are making claims that suddenly alert the host society to take notice of their presence. New Muslim claims include the right to build new mosques, the demand for separate burial grounds, the right to wear 'decent clothes' and the right not to face job discrimination because of their origins. The combination of this assertive Islamic presence in the West and the challenges to secularism in Iran and Afghanistan are what prompted many Western decision-makers and scholars to misconstrue 'Islamism' as new and different from the expressions of political Islam in the past. 


\section{Notes}

1. Italics mine.

2. This is another term for 'Islamist movements' in Kepel's work.

3. Burgat does argue that 'the political mobilisation of traditional religious mystics is not without rapport to Islamism. The Senusiyya was one of the first vectors to the resistance against French colonial invasion. A simple recollection of the role of the Sufi brotherhoods in the resistance to colonialism from Algeria to Sudan to the Libyan Senoussi is enough to justify nuances' ('la mobilisation des mystiques religieux de type traditionnel n'est pas sans rapport avec l'islamisme. La Senousissya fut l'un des premiers vecteurs à la résistance à la pénétration française ...(Burgat 1988:19, n.18). Yet he does not draw the full implications of this as he concurs with the notion that the Muslim Brothers are the first Islamists.

4. This movement of thought is identified in Roy's work as 'Islamism'.

5. The Arab medieval writers gave the name Bilad al-Sudan (Land of the Blacks) to Sub-Saharan Africa.

6. Because of lack of space the availability of a substantial body of literature on these revolutions, I will not discuss them in detail here, but I refer to Curtin 1971; Last 1987; Robinson 2000.

7. Islamic theologians have utmost contempt of the pre-Islamic era, which they have named as Jahiliyya, literally 'ignorance' in reference to the fact that people did not worship one God.

8. This classification is based on my personal interpretation and does not necessarily reflect the self-identification of the scholars whose views I discuss in this section.

\section{Bibliography}

Alagha Joseph, 2005, 'Hizballah After the Syrian Withdrawal', Middle East Report, 237, Winter: 34-39.

Alagha Joseph, 2006, The Shifts in Hizbullah's Ideology: Religions Ideology, Political Ideology, and Political Program, Amsterdam: Amsterdam University Press.

Anderson, Lisa, 1997, Fulfilling Prophecies: State Policy and Islamist Radicalism, in John L. Esposito, ed., Political Islam: Revolution, Radicalism, or Reform, Boulder, CO: Lynne Rienner: 17-33.

Beinin, Joel and Joe Stork, 1997, Political Islam. Berkeley and Los Angeles: University of California Press.

Bobboyi, Hamid, 2008, 'Ajami Literature and the Study of the Sokoto Caliphate', in Shamil Jeppie and Souleymane Bachir Diagne, eds, The Meanings of Timbuktu, Cape Town: HSRC Press in association with CODESRIA, 123-34.

Bonet-Maury, G., 1906, L'islamisme et le christianisme en Afrique, Paris: Hachette.

Brenner, Louis, 1987, 'Sufism in Africa in the Seventeenth and Eighteenth Century’, in Islam et sociétés au sud du Sahara, No. 2: 80-92. 
Brenner, Louis, 2000, Controlling Knowledge: Religion, Power and Schooling in a West African Muslim Society, London: Hurst.

Burgat, François, 1988, Lislamisme au Maghreb: La voie du Sud. Paris: Karthala.

Carothers, Thomas, 2002, 'The End of the Transition Paradigm', Journal of Democracy, 13/2: 5-21.

Curtin, Philip, 1977, 'Jihad in West Africa: Early phases and inter-relations in Mauritania and Senegal', Journal of African History, 12/1: 11-24.

El-Tahri Jihan [producer and director], 2005 The House of Saud, Videodisc: Frontline co-production with Alegria and Rain Media, Inc. in association with the BBC and Arte.

Esposito, John L., 1984, Islam and Politics. New York: Syracuse University Press.

Esposito, John L. and James Piscatori, 1990 'The Global Impact of the Iranian Revolution: A Policy Perspective', in John L. Esposito, ed., The Iranian Revolution: Its Global Impact, Miami: Florida International University Press: 317-28.

Garcia, Sylvianne, 1997, 'Al-Hajj Seydou Nourou Tall, "grand marabout" tijani: L'histoire d'une carrière (v. 1880-1980)', in Jean-Louis Triaud and David Robinson, eds, Le temps des marabouts: Itinéraires et stratégies islamiques en Afrique occidentale française v. 1881-1960, Paris: Karthala.

Geertz, Clifford, 1968, Islam Observed, Chicago and London: Chicago University Press.

Gellner, Ernest, 1969, Saints of the Atlas, London: Weidenfeld \& Nicolson.

Gellner, Ernest, 1981 Muslim Society, Cambridge: Cambridge University Press

Gill, Anthony and Arang Keshavarzian, 1999, 'State Building and Religious Resources: An institutional theory of church-state relations in Iran and Mexico', Politics \& Society, 27/3: 431-65.

Gold, Dore, 2003, Hatred's Kingdom: How Saudi Arabia Supports the New Global Terrorism, Washington, DC: Regnery Publishing.

Hiskett, Mervyn, 1984, The Development of Islam in West Africa, London: Longman.

Houdas, Octave, 1908, L'islamisme, Paris: Ernest Leroux.

Hourani, Albert, 1983, Arabic Thought in the Liberal Age, 1789-1939, Cambridge: Cambridge University Press.

Kalyvas, Stathis, 2000, 'Commitment Problems in Emerging Democracies: The case of religious parties', Comparative Politics, 32/4: 379-98.

Kane, Ousmane, 2003, Muslim Modernity in Postcolonial Nigeria, Leiden: E. J. Brill.

Kane, Ousmane and Leonardo Villalon, 1998, 'Entre confrérisme, réformisme et islamisme', in Ousmane Kane and Jean-Louis Triaud, eds, Islam et islamisme au sud du Sahara, Paris: Karthala: 263-310.

Kepel, Gilles, 1991, Les banlieues de l'islam, Paris: Seuil.

Kepel, Gilles, 1991, The Revenge of God: The Resurgence of Islam, Christianity and Judaism in the Modern World (trans. Alan Braley), University Park, PA: Pennsylvania State University Press.

Kepel, Gilles, 2000, Jihad: expansion et déclin de l'islamisme, Paris: Gallimard.

Kepel, Gilles, 2004, The War for Muslim Minds: Islam and the West, Cambridge, MA: Harvard University Press. 
Kifner, John, 2005, 'Lebanese Rivals, in a Tangled Web of Alliances, Face Off in a Crucial Stage in Elections', The New York Times, 12 June: 16.

Kurzman, Charles, ed., 1998, Liberal Islam: A Sourcebook, New York: Oxford University Press.

Last, Murray, 1987, 'The Jihad Movements of the Nineteenth Century', in J. F. Ade Ajayi and Michael Crowder, eds, History of West Africa, Vol. 2. London: Longman: 1-47.

Levitsky, Steven and Lucan A. Way, 2002, 'Elections Without Democracy: The Rise of Competitive Authoritarianism', Journal of Democracy, 13/2: 51-65.

Levtzion, Nehemia and Randall Pouwels, 2000, 'Patterns of Islamization and Varieties of Religious Experience among Muslims of Africa', in Nehemia Levtzion and Randall Pouwels, eds, The History of Islam in Africa, Athens, OH/ Oxford/Cape Town: Ohio University Press/James Currey/David Philip.

Loimeir, Roman, 2003, 'Patterns and Peculiarities of Islamic Reform in Africa', Journal of Religion in Africa, 33/3: 237-62.

Loimeir, Roman, 2005, 'Is There Something like "Protestant Islam"?', Die Welt des Islams, 45/2: $216-54$.

Mamdani, Mahmood, 2004, Good Muslim, Bad Muslim: America, The Cold War and the Roots of Terror, New York: Pantheon Books.

Martin, Bradford, 2003, Muslim Brotherhoods in Nineteenth Century Africa, Cambridge: Cambridge University Press.

Martinez, Luis, 2000, Algerian Civil War 1900-1998, London: Hurst.

Meier, Fritz, 1985, 'Eine Auferstehung Mohammads bei Suyuti', Der Islam: Zeitschrift für Geschichte und Kultur des Islamischen Orient, 62: 20-58.

Mitchell, Richard Paul, 1969, The Society of the Muslim Brothers, London: Oxford University Press.

Ould Abdallah, Deddoud, 1997, 'Guerre sainte ou sédition blâmable: un débat entre cheikh Sa'd Buh et son frère cheikh Ma al-Ainin', in Jean-Louis Triaud and David Robinson, eds, Le temps des marabouts: Itinéraires et stratégies islamiques en Afrique occidentale française v. 1881-1960, Paris: Karthala: 119-53.

Pape, Robert, 2005, Dying to Win: The Strategic Logic of Suicide Terrorism, New York: Random House.

Rahman, Fazlur, 1977, 'Revival and Reform', in P.M. Holt, Ann K.S. Lambton and Bernard Lewis, eds, The Cambridge History of Islam, Cambridge: Cambridge University Press.

Rahman, Fazlur, 2000, Revival and Reform: A Study of Islamic Fundamentalism, Oxford: Oneworld.

Rashid, Ahmed, 2000, Taliban: Militant Islam, Oil, and Fundamentalism in Central Asia, New Haven, CT: Yale University Press.

Robinson, David, 2000, 'Revolutions in the Western Sudan', in Nehemia Levtzion and Randall Pouwels, eds, The History of Islam in Africa, Athens, OH/Oxford/ Cape Town: Ohio University Press/James Currey/David Philip: 131-52.

Roy, Olivier, 1994, The Failure of Political Islam (Carol Volk trans), Cambridge, MA: Harvard University Press. 
Roy, Olivier, 2004, Globalized Islam: The Search for New Ummah, New York: Columbia University Press.

Salih, Ali Karrar, 1992, The Sufi Brotherhoods in the Sudan, Evanston, IL: Northwestern University Press.

Samson, Fabienne, 2005, Les marabouts de l'islam politique: le Dahiratoul Moustarchina wal Moustarchidaty: un mouvement néo-confrérique sénégalais, Paris: Karthala.

Schultze, Reinhard, 1990, Islamischer Internationalismus im 20. Jahrhundert : Untersuchungen zur Geschichte der Islamischen Weltliga, Leiden: E. J. Brill.

Schwartz, Stephen, 2002, The Two Faces of Islam: The House of Saud from Tradition to Terror, New York: Doubleday.

Seeseman, Rudiger, 2004, 'Nach Der "Flut” Ibrahim Niasse (1900-1975) Sufik und Gessellschaft in Westafrika', Habilitationsschrift, Universität Bayreuth, Sprach und Literaturwissenschaftlichen Fakultät.

Triaud, Jean-Louis, 1995, La légende noire de la Sanûsiyya: Une confrérie musulmane sous le regard français (1840-1930), Paris: Editions de la Maison des Sciences de l'Homme, tomes $1 \& 2$.

Triaud, Jean-Louis and David Robinson, 1997, Le temps des marabouts: itinéraires et stratégies islamiques en Afrique occidentale française v. 1881-1960, Paris: Karthala.

Triaud, Jean-Louis and David Robinson eds, 2000, La Tijaniyya: une confrérie soufie à la conquête de l'Afrique, Paris: Karthala.

Villalon, Leonardo, 1995, Islamic Society and State Power in Senegal: Disciples and Citizens in Fatick, Cambridge: Cambridge University Press.

Villalon, Leonardo and Ousmane Kane, 1998 'Senegal: The Crisis of Democracy and the Emergence of an Islamic Opposition', in Leonardo Villalon and Phillip Huxtable, eds, The African State at A Critical Juncture: Between Disintegration and Reconfiguration, Boulder, CO: Lynne Rienner: 143-66.

Voll, John, 1994, Islam: Continuity and Change in the Modern World, Syracuse: New York University Press.

Wiktorowicz Quintan and Karl Kaltenthaler, 2006, 'The Rationality of Radical Islam', Political Science Quarterly, 121/2: 295-319.

Wilks, Ivor, 2000, 'The Juula and the Expansion of Islam into the Forest', in Nehemia Levtzion and Randall Pouwels, eds, The History of Islam in Africa, Athens, OH/Oxford/Cape Town: Ohio University Press/James Currey/David Philip. 